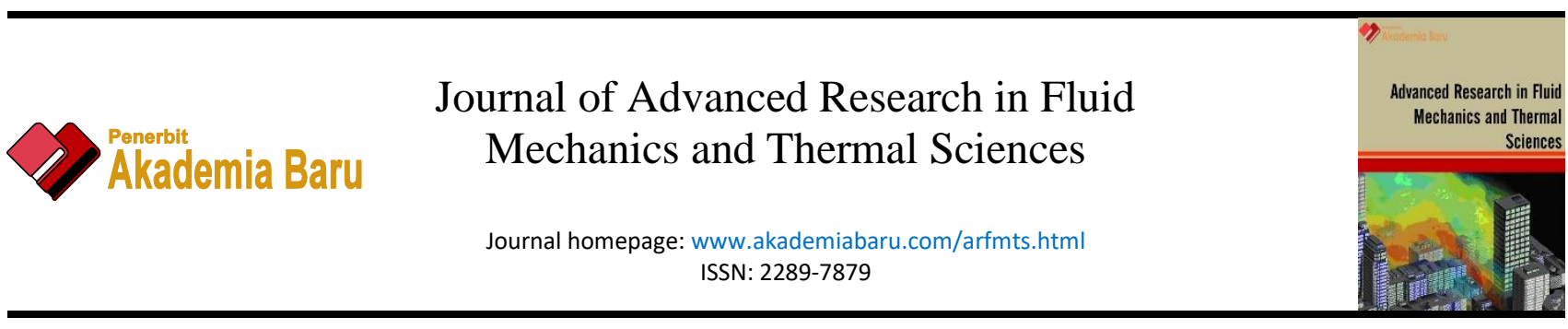

\title{
Progress in Glass-Ceramic Seal for Solid Oxide Fuel Cell Technology
}

\author{
Gunawan $^{1, *}$, Sulistyo $^{1}$, Iwan Setiawan ${ }^{2}$ \\ Department of Mechanical Engineering, Diponegoro University, Semarang, Indonesia \\ 2 Department of Electrical Engineering, Diponegoro University, Semarang, Indonesia
}

\section{ARTICLE INFO ABSTRACT}

\section{Article history:}

Received 15 October 2020

Received in revised form 9 March 2021

Accepted 13 March 2021

Available online 7 April 2021
Keywords:

Glass-ceramic; seal; SOFC; solid oxide

\begin{abstract}
Solid oxide fuel cells (SOFCs) have emerged as promising energy conversion devices nowadays. SOFC consists of several components such as cathode, anode, electrolyte, interconnects, and sealing materials. In planar SOFC stack construction, the sealant and interconnection functions play an important role. Glass and ceramics are quite popularly used as SOFC sealing materials to achieve several functions including preventing leakage of fuel and oxidants in the stack and electrically isolating cells in the stack. In this review, material preparation, material composition, ceramic properties especially thermal properties are compared from various systems that have been developed previously. The main challenges and complexities in the functional part of SOFC sealants include: (i) chemical incompatibility and instability in the oxidizing and reducing environment by adjusting the value of the thermal expansion coefficient (CTE) with the interconnecting material during SOFC operation, and (ii) insulation of oxidizing fuels and gases by matching CTE anode and cathode. Also, the sealant glass transition determines the maximum permissible working temperature of the SOFC. The choice of method and analysis will provide data on various ceramic attributes. The search for thermal attributes consisting of Glass transition ( $\mathrm{Tg}$ ), Deformation temp (Td), Crystallization temp ( $T x)$, Melting pt $(T m)$ became a focus on SOFC sealant development.
\end{abstract}

\section{Introduction}

Solid Oxide Fuel Cell (SOFC) technology shows great potential in distributed generator applications. It is because of the contribution of strong electrolyte properties in reforming gas fuels and high efficiency [1]. The basic components of anode, electrolyte, cathode, interconnect, and sealant work performs with SOFC at medium temperature through an electrochemical process. Particular role is given to each ceramic material component thus could get along even at hard operation cycles [2]. Investigations of Rigid Bonded Sealing for SOFC applications have been carried out from designing to testing by varying some compositions of ceramic glass.

The required performance of material was attempted by combining basic composition of silica dioxide $\left(\mathrm{SiO}_{2}\right)$ with other oxides to generate various glass-ceramic material compositions. Applying

\footnotetext{
* Corresponding author.

E-mail address: gunawan@unissula.ac.id
}

https://doi.org/10.37934/arfmts.82.1.3950 
Silica Dioxide $\left(\mathrm{SiO}_{2}\right)$ as the base material, a new developed ceramic sealing material was produced. It could be fabricated by incorporating few types of oxide materials $\left(\mathrm{AlO}_{3}, \mathrm{BaO}, \mathrm{CaO}, \mathrm{MgO}, \mathrm{TiO}_{2}\right.$, and others) to strengthen the character [3-7].

The performance of solid oxide fuel cells (SOFC) is very challenging due to the complicated generation of sealing material thus appropriate as air and fuel filter. Some attempts have been applied to obtain the suitability to the required conditions, mechanical integrity and stability inclusive of rigid seals (no-load applied during operation) and compressive seals (loads applied during operations) [8]. Identification of heat source generation and mechanism of heat transfer, as well as the relationship with temperature, gradient and thermal stress distribution in each component of the SOFC cell is of important [9].

The space of cell and reaction chamber is commonly enclosed using seals. A material resistant to temperature cycle loads like ceramic is generally used to produce seal, while the CTE below the material of electrode which has high resistivity and difficult to crack [10]. To generate effective bonding to the surface, rigid seals are among the choice. Better properties are given to rigid seals than that of compressive seals due to the relatively simple bonding of ceramic and metal parts. This choice is even better than utilizing external sealing load.

Good thermal, chemical, and dielectric properties have been performed by ceramics. The application of ceramic as cup has also shown a substantial benefit than that of inorganic materials. A variety of modification in the composition as well as the development of special microstructure must be taken into account. The tendency of crystalline formation or large glass residues commonly observed. Ceramics composed of some phases of glass and crystal. Crystallization process is conducted to produce glass-ceramics from materials of glass-based. The generated crystals straight extend in the phase of glass while the remaining glass composition is gradually changed. The production of glass-ceramic materials is initiated by the good synthesis of basic glass. Glass based material could be produced by various traditional and shaping methods, including sol-gel and chemical vapour deposition [11].

Despite the complicated and time-consuming processes of glass-ceramics production, the broad spectrum of chemical compound is of important to obtain various characteristics. The production of glass-ceramic offers important advantage of various special microstructures, as shown on Table 1. The major groups of microstructures resulted in glass-ceramics cannot be generated in other materials.

Table 1

Beneficial properties of glass and ceramic [11]

\begin{tabular}{ll}
\hline Processing properties & $\begin{array}{l}\text { Rolling, casting, pressing, spin casting, press-and-blow method, drawing } \\
\text { Limited and controlled shrinkage } \\
\text { There is no porosity in monolithic glass ceramics }\end{array}$ \\
Thermal properties & $\begin{array}{l}\text { Expansion can be controlled as desired, depending on the temperature, so zero or } \\
\text { even the value of the thermal expansion coefficient becomes negative } \\
\text { High-temperature stability }\end{array}$ \\
Chemical properties & $\begin{array}{l}\text { Resorb ability or high chemical resistance } \\
\text { Mechanical properties }\end{array}$ \\
Mectrical and magnetic \\
High strength and toughness \\
properties & $\begin{array}{l}\text { Isolation capability (constant and low dielectric loss, high resistivity, and breakdown } \\
\text { voltage) } \\
\text { lon conductivity and superconductivity } \\
\text { Ferromagnetism }\end{array}$ \\
\hline
\end{tabular}


A different structure is also given by the glass phase. Moreover, different morphologies could generate various microstructures. More extensive variants of properties are offered by the crystalline phase. Defined by the growth mode, special morphology associate with the specific structure is obtained.

\subsection{Sealant Ceramic Properties}

Study on the invention of suitable glass material revealed that the technology applied in the formation of primary glass could also be utilised to glass-ceramics. As for some properties that need attention including

i. Thermal Properties, a special benefit in the formation of glass-ceramics is that products show almost zero shrinkage that could be made $[12,13]$.

ii. Chemical properties, extending from resorbability to chemical stability, could be defined related to the nature of the crystal, the glassy phase, or the interface properties between the crystal and glassy phases. As a result, ceramics that can be resorbable or chemically stable can be produced [14].

iii. Mechanical Properties, although the highest value of flexural strength measured for metal alloys has not been achieved in glass ceramics, it is still possible to achieve flexural strengths of up to $500 \mathrm{MPa}$ [15].

iv. Electrical and Magnetic Properties, glass-ceramics with special electrical or magnetic properties can also be produced. Electrical properties are very important if the material is used for insulators in the electronics or micro-electronics industry $[16,17]$.

\subsubsection{Heat properties}

In crystalline materials such as metals, metals have a certain temperature when they change their phase. this is different from glass or non-crystalline materials which do not have a certain temperature when they turn into solids.

In glass material, when the temperature drops, the glass is thicker. In addition, glass has a specific temperature and volume dependence, (volume per unit mass or the inverse of density). Also important in glass forming operations is the characteristic relationship between viscosity and temperature. As shown in the following Table 2 shows the logarithmic scale of viscosity and temperature for fused silica, high silica, borosilicate and soda-lemon glass.

Table 2

Heat properties [18]

\begin{tabular}{lll}
\hline Name & $\eta(P a . s)$ & Remarks \\
\hline Melting pt $\left(T_{m}\right)$ & $10^{1}$ & \\
Melting Range & $10^{0.5}-10^{1.5}$ & Melting, fining \\
Working pt $\left(T_{m}\right)$ & $10^{3}$ & \\
Working range & $10^{2}-10^{6}$ & Forming \\
Liquidus temp $\left(\mathrm{T}_{\mathrm{I}}\right)$ & $\sim 10^{4}$ & No crystallization for $\mathrm{T}>\mathrm{T}_{\mathrm{I}}$ \\
Flow point & $10^{4}$ & \\
Softening point $\left(\mathrm{T}_{\text {lit }}\right)$ & $10^{6.6}$ & Littleton, flow under own weight \\
Crystallization temp $\left(\mathrm{T}_{\mathrm{x}}\right)$ & $\sim 10^{7}$ & No crystallization for $\mathrm{T}<\mathrm{Tx}$ \\
Deformation temp $\left(\mathrm{T}_{\mathrm{d}}\right)$ & $10^{10}-10^{11}$ & Dilatometric: expansion compensated by viscous flow \\
Glass transition $\left(\mathrm{T}_{\mathrm{g}}\right)$ & $10^{11}-10^{12}$ & \\
Annealiang pt $\left(\mathrm{T}_{\mathrm{ap}}\right)$ & $10^{12}$ & Internal stresses relieved $<15$ min \\
Strain pt $\left(\mathrm{T}_{\mathrm{sp}}\right)$ & $10^{13.5}$ & Internal stresses relieved $<15 \mathrm{hrs}$ \\
\hline
\end{tabular}




\subsection{Character Strengthening Oxides}

Boron oxide is a major component to silicate glasses. Boron oxide is mostly incorporated to reduce glass viscosity as well as to reduce the softening point and the transition temperature of glass from SOFC sealants [18]. Boron oxide plays important role in enhancing the coefficient of thermal expansion, for compositions where only the $\mathrm{B}_{2} \mathrm{O}_{3} / \mathrm{SiO}_{2}$ ratio is changed $[16,19]$. While boron oxide as a whole generates a decline in the glass transition temperature, the coefficient of thermal expansion for most glasses increases after crystallization. The amorphous structure is stabilized by boron oxide as required by the surge of energy supported for Boron Power Increase (B / Al ratio). Aluminium is another important component of glass-ceramics. It has tetrahedral coordination and substitute silicon in glass tissue, but at a greater concentration acting as a tissue modifier. The double role of aluminium has led to aluminium reports which inhibit [and increase crystallization. The addition of aluminium has also been revealed to minimize the formation of cristobalite, which as mentioned previously could induce cracking [20,21].

To govern the viscosity, zinc or lanthanum could be major materials to be incorporated to glassceramics. The addition of lanthanum increases the softening point and the coefficient of thermal expansion $[16,22]$.

Chemical contability of sealants and other fuel cell components is of important. Good chemical compatibility of glass-ceramic sealants and yttria-stabilized zirconia electrolytes is performed. It is revealed that silicates composed of barium, calcium and / or magnesium could produce adherents and interface stabilizers with yttria-stabilized zirconia. More prevalent reactions are occured with interconnecting materials, mainly due to chromium, which is usually available in ceramic and metal interconnecting materials. Among the most applied alkaline earth oxides, silicates composed of barium oxide are the most reactive $[20,23]$ and while compounds composed of magnesium oxide are the most compliant $[19,24]$.

However, this reaction is more widespread in silicate composed of barium, which, even in the availability of calcium in calcium barium aluminosilicate forms $\mathrm{BaCrO}_{4}$. Thus, the improvement in matching thermal expansion given by the addition of barium is offset by an increase in reaction with the interconnect material.

\section{Rigid Bonded Sealant}

Glass or ceramic materials are commonly used to produces sealants for SOFC. The materials could withstand fuel cells operation for more than 1000 hours in the absence of significant degradation. Most glasses and glass-ceramics materials of sealants commonly composed of alkali metals [18]. Despite the application of some alkali metals-contained-glasses for sealants in SOFC, their reactive properties with other fuel cell components must be taken into account. It is therefore, alkali-based ground glass is more commonly applied in the applications of SOFC. The glass transition temperature (Tg) and the coefficient of thermal expansion (CTE) is the consideration to determine the suitable glass sealants. The importance of glass transition temperature is due to ensure the adequacy of glass flowing thus provide a sufficient sealing while maintaining sufficient rigidity for mechanical integrity. Viscosity defines the softening temperature (Ts), which is a more direct measurement of glass flow characteristics. However, trends in Ts usually follow trends for Tg, which are easier to be determined. As a result, $\mathrm{Tg}$ data are available for various glass compositions. The coefficient of thermal expansion must be appropriate with other cell components, such as Yttria-stabilized (YSZ) electrolytes and interconnect material, to reduce thermal pressure $[12,13]$. 
The specific composition that meets both criteria is ceramic containing barium, which has a relatively large coefficient of thermal expansion. Glass-ceramics are develpoed with deliberate and controlled glass crystallization that usually enhance the strength and allows the properties control through total control of material composition and phase crystalline properties [25].

The expansion thermal coefficient of $\mathrm{BaO}-\mathrm{MgO}-\mathrm{SiO}_{2}$ and $\mathrm{BaO}-\mathrm{ZnO}-\mathrm{SiO}_{2}$ increases with the addition of $\mathrm{BaO}$ concentration at constant $\mathrm{SiO}_{2}$ content [26]. The increment of the thermal expansion coefficient was due to the large coefficient of thermal expansion of the generated barium silicate $\left(\mathrm{BaSiO}_{3}\right)$ compared to, for example, enstatite $\left(\mathrm{MgSiO}_{3}\right)$.

Hexacelsian has a high thermal expansion coefficient required for SOFC applications, while monocelsian has a very low thermal expansion coefficient. For some compositions, silica (quartz or cristobalite) can also be formed $[15,27]$. Cristobalite is particularly problematic because of the displacement transformations on cooling with a related reduction of volume, which can lead to cracking. Strontium forms a solid solution with barium in a celsian crystalline structure and has been shown to stabilize the monocelsian phase. Other alkaline-earth oxides do not dissolve in the celsian phase but instead form other phases. Calcium oxide is often added to form a barium-calcium aluminosilicate (BCAS) sealant, in this case, an additional phase, a barium calcium orthosilicate phase $\left(\mathrm{Ba}_{3} \mathrm{CaSi}_{2} \mathrm{O}_{8}\right)$, with a large thermal expansion coefficient formed during crystallization $[28,29]$. The addition of magnesium oxide to the glass-ceramic barium aluminosilicate resulted in the formation of enstatite $\left(\mathrm{MgSiO}_{3}\right)$ and silica together with celsian. There is a strong tendency for celsian formation as evidenced by only $3 \% \mathrm{BaO}$ and the presence of only celsian and barium silicate in a glass containing $15 \% \mathrm{MgO}$. Magnesium aluminosilicate without barium oxide forms cordierite $\left(\mathrm{Mg}_{2} \mathrm{Al}_{4} \mathrm{Si}_{5} \mathrm{O}_{18}\right)$, which has a very low coefficient of thermal expansion. While certain crystalline phases formed in glassceramics are very important to control their properties, the kinetics of crystallization must also be controlled.

\subsection{Self-Healing Sealant}

The development of recyclable thermal sealants is a major part of the problem hindering the development of SOFCs. Sealants must be thermally and chemically stable in a reduction and oxidation environment and must remain mechanically and electrically strong for long-term operation for several thousand hours. Seal cracking can occur during thermal cycles when different SOFC components with different coefficients of thermal expansion (CTE) are sealed together.

Singh [30] proposed and developed the concept of SOFC glass seals that can heal/repair themselves. These seals were developed for potential applications in SOFCs to increase SOFC cyclability and service life. Self-healing behavior from glass can occur alone, showing various stages of self-recovery from cracks created by micro indentation techniques. Self-repairing cracks generated during SOFC operation, increasing seal life and reliability [26] established self-healing behavior from the composition of barium-lanthanum-borosilicate (mol.\%) $30 \mathrm{BaO}-10 \mathrm{La}_{2} \mathrm{O}_{3}-20 \mathrm{~B}_{2} \mathrm{O}_{3}-40 \mathrm{SiO}_{2}$. This glass has a glass transition temperature $(\mathrm{Tg}) 682^{\circ} \mathrm{C}$ and a CTE of $9.72-8.69 \times 10^{6}{ }^{0} \mathrm{C}^{1}$ [31] showed that crystal products such as $\mathrm{CaB}_{4} \mathrm{O}_{7}$ and $\mathrm{CaB}_{2} \mathrm{O}_{4}$ from glass having a $33 \mathrm{CaO}-67 \mathrm{~B}_{2} \mathrm{O}_{3}$ (mol.\%) Composition exhibit self-healing behavior. This glass has a glass transition temperature ( $\mathrm{Tg}$ ) of 655 ${ }^{\circ} \mathrm{C}$. 


\subsection{Non-Self-Healing}

The composition of the ceramic rigid sealant materials is very diverse in element and composition. The use of certain elements as bases and other oxides as character reinforcement is known as several types of sealants.

\subsubsection{Silicate sealant}

Glass-ceramics with a composition (mol.\%) 55. $\mathrm{SiO}_{2}-27 . \mathrm{BaO}-18 . \mathrm{MgO}$ presents properties suitable for application of a sealant in SOFCs. This demonstrates good integration with the 8YSZ electrolyte and with the aluminum $\mathrm{FeCr}$ based interconnect material. This glass has a glass transition temperature $(\mathrm{Tg})$ of $715 \pm 3^{\circ} \mathrm{C}$ and a CTE of $8.1 \pm 0.5 \times 10^{6}{ }^{\circ} \mathrm{C}^{1}$. However, the seal suffers delamination when applied to Crofer stainless steel ferritic based on chromium 22 (CTE $12.8 \times 10^{6}{ }^{0} \mathrm{C}^{1}$ ), one of the most widely used interconnection materials in SOFCs, due to $\mathrm{BaCrO}_{4}\left(\mathrm{CTE} 18-20 \times 10^{6}{ }^{0} \mathrm{C}^{1}\right.$ ) precipitation at the interface. It was seen that there was a large mismatch between the glass CTE (CTE $8.1 \pm 0.5 \times 10^{6}{ }^{0} \mathrm{C}^{1}$ ) and $\mathrm{BaCrO}_{4}\left(\mathrm{CTE} 18-20 \times 10^{6}{ }^{0} \mathrm{C}^{1}\right)$, the resulting crack failed $[16,32]$.

\subsubsection{Aluminosilicate sealant}

Aluminosilicate glass and glass-ceramic sealants are for SOFCs in calcium-magnesium-aluminumsilicate (CMAS) systems. The composition (mol.\%) of the glass is $38.7 \mathrm{CaO}-9.7 \mathrm{MgO}-12.9 \mathrm{Al}_{2} \mathrm{O}_{3^{-}}$ $38.7 \mathrm{SiO}_{2}$. This glass has a glass transition temperature $(\mathrm{Tg})$ of $732 \pm 3^{\circ} \mathrm{C}$ and a CTE of $9.7 \pm 0.1 \times 10^{6}$ ${ }^{0} \mathrm{C}^{1}[32]$.

\subsubsection{Borosilicate sealant}

The borosilicate ceramics replace the $\mathrm{SiO}_{2}$ component of the $55 \mathrm{SiO}_{2}-27 \mathrm{BaO}-18 \mathrm{MgO}$ (mol.\%) Silicate glass with $\mathrm{B}_{2} \mathrm{O}_{3}$ and $\mathrm{PbO}$. Thus, we get a glass and borosilicate glass $\mathrm{SOFC}$ sealant which has a composition (mol.\%) of $40 \mathrm{SiO}_{2} 27 \mathrm{BaO}-18 \mathrm{MgO}-5 \mathrm{~B}_{2} \mathrm{O}_{3}-10 \mathrm{PbO}$ with CTE $12.3 \pm 0.5$ and $\mathrm{Td} 512 \pm 5 \mathrm{x}$ $10^{6}{ }^{0} \mathrm{C}^{1}$. Similarly, replacing $\mathrm{SiO}_{2}$ with $\mathrm{B}_{2} \mathrm{O}_{3}$ and $\mathrm{MgO}$ by $\mathrm{ZnO}$, we obtained again the composition of borosilicate glass and ceramic SOFC glass sealants (mol.\%) $50 \mathrm{SiO}_{2}-27 \mathrm{BaO}-10 \mathrm{MgO}-5 \mathrm{~B}_{2} \mathrm{O}_{3}-8 \mathrm{ZnO}$ with CTE of $8.9 \pm 0.5 \times 10^{6}{ }^{0} \mathrm{C}^{1}$ and $\mathrm{Td} 656 \pm 5^{\circ} \mathrm{C}[6]$.

Both glasses offer a CTE that is suitable for use in SOFCs. The addition of $\mathrm{B}_{2} \mathrm{O}_{3}$ provides better wettability of glass in steel and better bonding, which inhibits the direct reaction between chromium oxide and the barium-rich crystalline phase to form $\mathrm{BaCrO}$. This minimizes CTE mismatch (as shown under silicate seals), resulting in seal cracking. Recently, Borhan et al., [33] have reported on adjusting the thermal properties of a borosilicate glass-ceramic seal for SOFC. Optimized compositions, CTE, $\mathrm{Tg}$, and $\mathrm{Td}$ are $30 \mathrm{SiO}_{2}-20 \mathrm{BaO}-20 \mathrm{SrO}-30 \mathrm{~B}_{2} \mathrm{O}_{3}(\mathrm{~mol} . \%), 11.7 \times 10^{6}{ }^{\circ} \mathrm{C}^{1}, 650^{\circ} \mathrm{C}$, and $663^{\circ} \mathrm{C}$, respectively.

\subsubsection{Boroaluminosilicate sealant}

The performance of the boroaluminosilicate SOFC seal is known to be the best compared to other types of silicate-based SOFC sealants. The composition and thermal properties of some of the boroaluminosilicate SOFC seals shows that the glass modifier is an alkaline earth metal ion. This is because the alkaline earth metal ions have different chemical properties such as field strength, ionic radius, and electronegativity, which greatly influence $\mathrm{CTE}, \mathrm{Tg}, \mathrm{Ts}$, crystallization behavior, electrical conductivity and glass reactivity [34]. 
Effect of $\mathrm{BaO}, \mathrm{SrO}, \mathrm{ZnO}, \mathrm{La}_{2} \mathrm{O}_{3}, \mathrm{~B}_{2} \mathrm{O}_{3}$, etc on various glass properties, for example, $\mathrm{B}_{2} \mathrm{O}_{3}$ reduces the viscosity and tendency of silicate glass crystallization (both of which are advantageous in SOFC sealant applications), whereas $\mathrm{Al}_{2} \mathrm{O}_{3}$ increases viscosity and increases chemical resistance $[3,21]$ reported the application of $\mathrm{BaO}-\mathrm{CaO}-\mathrm{Al}_{2} \mathrm{O}_{3}-\mathrm{B}_{2} \mathrm{O}_{3}-\mathrm{SiO}_{2}$ glass-ceramic seals in a large IT-SOFC planar including microstructure with SOFC components and open circuit stress variation (OCV).

\subsubsection{Composite sealant}

Two glasses of sodium-calcium-aluminosilicate ( $\mathrm{SACN1}, 45 \mathrm{SiO}_{2}-9 \mathrm{Al}_{2} \mathrm{O}_{3}-10 \mathrm{~B}_{2} \mathrm{O}_{3}-18 \mathrm{CaO}-18 \mathrm{Na}_{2} \mathrm{O}$, and $\mathrm{SACN}_{2}, 40 \mathrm{SiO}_{2}-9 \mathrm{Al}_{2} \mathrm{O}_{3}-10 \mathrm{~B}_{2} \mathrm{O}_{3}-18 \mathrm{CaO}-23 \mathrm{Na}_{2} \mathrm{O}$ (mol\%) is used for glass. Composite-dynamic seals for joining YSZ interconnect metals in SOFCs [35]. The sealant must endure several thousand thermal cycles during its service life. To improve the thermal cyclability of sealants, different approaches have been tried. In conventional compressed mica seals, it is identified that the main leak path is at the interface between the mica and the bonding material. This observation encourages to increase of the mica seal by adding surface glass interlayers [13] observed that the leakage rate is reduced by hundreds.

\section{Methodology}

This paper examines the test of rigid bonded sealants, especially glass or silicate-based glass. One of the seal requirements stated is that it is stable to work at intermediate temperatures and compatibility with other parts of the SOFC cell. Material testing will be focused on thermal properties. In preparing samples for the test, observe the silica composition in various systems (BAS, BCS, etc.). The silicate seal system consists of synthesis of $\mathrm{SiO}_{2}$ which is dominant in quantity against a number of other oxides. The composition can be determined based on the percentage by weight or molarity of the oxide compound involved. Another technique is to adjust the composition with a measurable variable of each oxide added.

The process of producing sol mixtures by synthesizing various oxides and forming test samples can take several routes. Production methods of test samples generally use variations in temperature treatment when sintering or varying the duration of time when mixing with a ballmill. Characteristics based on thermal properties to determine the value of thermal expansion coefficient (CTE), Glass Transition (Tg) and Deformation Temperature (Td), Crystallization Temperature (Tx) and Melting Temperature (Tc). The thermal characteristics of glass and composite glass powders, the coefficient of thermal expansion (CTE, between 200 and $400^{\circ} \mathrm{C}$ ), glass transition temperature $(\mathrm{Tg})$ and softening temperature (Td), were measured by dilatometer (ex. DIL402C, NETZSCH, Inc.).

\section{Results}

Rigid sealant ceramic materials have a wide variety of elements and compositions. In Table 3 there is a material development using $\mathrm{SiO}_{2}$ as a ceramic base material with other oxides as character reinforcement. Several previous research searches obtained data in mapping material preparation techniques, test sample treatment and thermal character testing. The large variety of ceramic properties obtained in previous studies shows the progress of ceramic development from various requirements. The exposure in the table is a compilation of various combinations of sample material synthesis related to thermal properties. 
Table 3

Material and thermal properties

\begin{tabular}{|c|c|c|c|c|c|c|c|c|c|c|c|c|c|c|}
\hline \multirow[t]{2}{*}{ No } & \multirow[t]{2}{*}{ Material } & \multicolumn{7}{|c|}{ Component } & \multicolumn{5}{|c|}{ Thermal Properties } & \multirow[t]{2}{*}{ Ref. } \\
\hline & & $\mathrm{SiO}_{2}$ & $\mathrm{Al}_{2} \mathrm{O}_{3}$ & $\mathrm{~B}_{2} \mathrm{O}_{3}$ & $\mathrm{BaO}$ & $\mathrm{MgO}$ & $\mathrm{CaO}$ & Others (mol.\%) & CTE & $\mathrm{Tg}$ & $\mathrm{Td} / \mathrm{tp}$ & Tc & Tx & \\
\hline \multirow[t]{2}{*}{1} & $\mathrm{SiO}_{2}-\mathrm{B}_{2} \mathrm{O}_{3}-\mathrm{BaO}-\mathrm{MgO}$ & 40 & & 15 & 27 & 18 & & & {$\left[{ }^{0} \mathrm{C}^{-1}\right]$} & {$\left[{ }^{\circ} \mathrm{C}\right]$} & {$\left[{ }^{0} \mathrm{C}\right]$} & {$\left[{ }^{0} \mathrm{C}\right]$} & & [28] \\
\hline & & 40 & & 15 & 27 & 10 & & $\mathrm{ZnO} .8$ & & & & & & [28] \\
\hline 2 & $\mathrm{BaO}-\mathrm{Al}_{2} \mathrm{O}_{3}-\mathrm{SiO}_{2}[\mathrm{BAS}]$ & & & & & & & $\left(\mathrm{CoO}, \mathrm{CaO}, \mathrm{B}_{2} \mathrm{O}_{3}\right)$ & $6.15 \times 10^{-6}$ & & & & & {$[2]$} \\
\hline \multirow[t]{4}{*}{3} & $\mathrm{BaO}-\mathrm{CaO}-\mathrm{SiO}_{2}[\mathrm{BCS}]$ & 29.8 & & & 48.2 & & 6.1 & $\mathrm{Al}_{2} \mathrm{O}_{3}, \mathrm{~B}_{2} \mathrm{O}_{3}, \mathrm{~V}_{2} \mathrm{O}_{5}, \mathrm{ZnO}$ & & & & 732 & & [3] \\
\hline & & 31.3 & & & 50.6 & & 6.4 & $\mathrm{Al}_{2} \mathrm{O}_{3}, \mathrm{~B}_{2} \mathrm{O}_{3}$ & & & & 750 & & {$[3]$} \\
\hline & & 30.9 & & & 50.1 & & 6.3 & $\mathrm{Al}_{2} \mathrm{O}_{3}, \mathrm{~B}_{2} \mathrm{O}_{3}, \mathrm{~V}_{2} \mathrm{O}_{5}$ & & & & 742 & & [3] \\
\hline & & 30.1 & & & 48.7 & & 6.1 & $\mathrm{Al}_{2} \mathrm{O}_{3}, \mathrm{~B}_{2} \mathrm{O}_{3}, \mathrm{ZnO}$ & & & & 735 & & [3] \\
\hline \multirow[t]{4}{*}{4} & $\mathrm{BaO}-\mathrm{Al}_{2} \mathrm{O}_{3}-\mathrm{SiO}_{2}[\mathrm{BAS}]$ & 19 & 3 & 4 & 74 & & & $\mathrm{~B}_{2} \mathrm{O}_{3}$ & $9.7 \times 10^{-6}$ & 643 & 865 & & & [30] \\
\hline & & 20.5 & 4.5 & 3 & 72 & & & & $10.5 \times 10^{-6}$ & 678 & 886 & & & [30] \\
\hline & & 17 & 6 & 10 & 67 & & & & $8.8 \times 10^{-6}$ & 670 & 782 & & & [30] \\
\hline & & 17.5 & 4.5 & 9 & 69 & & & & $9.6 \times 10^{-6}$ & 680 & 788 & & & [30] \\
\hline \multirow[t]{3}{*}{5} & $\mathrm{CaO}-\mathrm{MgO}-\mathrm{Al}_{2} \mathrm{O}_{3}-\mathrm{SiO}_{2}$ & 50.4 & 8.3 & 5.8 & & 13 & 9.3 & $\mathrm{Na}_{2} \mathrm{O} 10.3, \mathrm{ZrO}_{2} 2.9$ & $9.5 \times 10^{-6}$ & 637 & 640 & & & [10] \\
\hline & & 46.3 & 9.0 & 6.3 & & 14.1 & 10.1 & Na2O 11.1, ZrO2 3.1 & & 605 & 616 & & & [10] \\
\hline & & 48.5 & 8.6 & 6.0 & & 13.5 & 9.6 & Na2O 10.7, ZrO2 3.0 & & 618 & 627 & & & [10] \\
\hline \multirow[t]{7}{*}{6} & $\mathrm{CaO}-\mathrm{SiO}_{2}-\mathrm{Al}_{2} \mathrm{O}_{3}-\mathrm{MgO}$ & 33 & 15 & & & 5 & 47 & C/S.1,42 NBO/T 1,94 & & & & & & [11] \\
\hline & & 35 & 15 & & & 5 & 45 & C/S.1,29 NBO/T 1,78 & & & & & & [11] \\
\hline & & 36 & 15 & & & 5 & 44 & C/S.1,22 NBO/T 1,71 & & & & & & [11] \\
\hline & & 38 & 15 & & & 5 & 42 & C/S.1,11 NBO/T 1,56 & & & & & & [11] \\
\hline & & 40 & 15 & & & 5 & 40 & C/S.1,00 NBO/T 1,44 & & & & & & [11] \\
\hline & & 44 & 15 & & & 5 & 36 & C/S.0,82 NBO/T 1,18 & & & & & & {$[6]$} \\
\hline & & 53 & 15 & & & 5 & 27 & C/S.1,51 NBO/T 0,77 & & & & & & {$[6]$} \\
\hline \multirow[t]{6}{*}{7} & $\mathrm{Y}_{2} \mathrm{O}_{3}-\mathrm{Al}_{2} \mathrm{O}_{3}-\mathrm{B}_{2} \mathrm{O}_{3}-\mathrm{SiO}_{2}$ & & & & & & & & & & & & & [17] \\
\hline & & 45 & 10 & 5 & 5 & & & $\mathrm{SrO} .25, \mathrm{Y}_{2} \mathrm{O}_{3} .10$ & $13.20 \times 10^{-6}$ & & & & & [17] \\
\hline & & 45 & 10 & 5 & 10 & & & $\mathrm{SrO} .20, \mathrm{Y}_{2} \mathrm{O}_{3} .10$ & $10.02 \times 10^{-6}$ & & & & & [17] \\
\hline & & 45 & 10 & 5 & 15 & & & SrO.15, $\mathrm{Y}_{2} \mathrm{O}_{3} .10$ & $11.4 \times 10^{-6}$ & & & & & [17] \\
\hline & & 45 & 10 & 5 & 20 & & & SrO.10, $\mathrm{Y}_{2} \mathrm{O}_{3} .10$ & $12.8 \times 10^{-6}$ & & & & & [17] \\
\hline & & 45 & 10 & 5 & 25 & & & $\mathrm{SrO} .5, \mathrm{Y}_{2} \mathrm{O}_{3} .10$ & $11.6 \times 10^{-6}$ & & & & & [17] \\
\hline \multirow[t]{6}{*}{8} & $\mathrm{Na}_{2} \mathrm{O}-\mathrm{SiO}_{2}$ & 70 & & & & & & $\mathrm{Na}_{2} \mathrm{O} .30$ & & & & & & \\
\hline & NS (quenched) & 70 & & & & & & $\mathrm{Na}_{2} \mathrm{O} .30$ & $15.8 \pm 0.1 \times 10^{-6}$ & $455 \pm 3$ & $500 \pm 3$ & & & [21] \\
\hline & 4NSF (heat treated) & 70 & & & & & & $\mathrm{Na}_{2} \mathrm{O} .30$ & $14.3 \pm 0.1 \times 10^{-6}$ & $476 \pm 3$ & $536 \pm 3$ & & & [21] \\
\hline & 8NSF (heat treated) & 70 & & & & & & $\mathrm{Na}_{2} \mathrm{O} .30$ & $13.8 \pm 0.1 \times 10^{-6}$ & $482 \pm 3$ & $527 \pm 3$ & & & [21] \\
\hline & NS $-100 h$ & 70 & & & & & & $\mathrm{Na}_{2} \mathrm{O} .30$ & $13.9 \pm 0.1 \times 10^{-6}$ & N/A & N/A & & & [21] \\
\hline & 4NSF-100h & 70 & & & & & & $\mathrm{Na}_{2} \mathrm{O} .30$ & $13.8 \pm 0.1 \times 10^{-6}$ & $\mathrm{~N} / \mathrm{A}$ & $\mathrm{N} / \mathrm{A}$ & & & [21] \\
\hline
\end{tabular}




\begin{tabular}{|c|c|c|c|c|c|c|c|c|c|c|c|c|c|c|}
\hline \multirow[t]{4}{*}{ No } & Material & \multicolumn{7}{|c|}{ Component } & \multicolumn{5}{|c|}{ Thermal Properties } & \multirow{2}{*}{$\frac{\text { Ref. }}{\mathrm{B}_{2} \mathrm{O}_{3}}$} \\
\hline & & $\mathrm{SiO}_{2}$ & $\mathrm{Al}_{2} \mathrm{O}_{3}$ & $\mathrm{~B}_{2} \mathrm{O}_{3}$ & & & $\mathrm{SiO}_{2}$ & $\mathrm{Al}_{2} \mathrm{O}_{3}$ & $\mathrm{~B}_{2} \mathrm{O}_{3}$ & & & $\mathrm{SiO}_{2}$ & $\mathrm{Al}_{2} \mathrm{O}_{3}$ & \\
\hline & 8NSF-100h (in air) & 70 & & & & & & $\mathrm{Na}_{2} \mathrm{O} .30$ & $11.7 \pm 0.1 \times 10^{-6}$ & $693 \pm 3$ & $765 \pm 3$ & & & {$[21]$} \\
\hline & $\begin{array}{l}\text { 8NSF-100h (in forming } \\
\text { gas) }\end{array}$ & 70 & & & & & & $\mathrm{Na}_{2} \mathrm{O} .30$ & $12.0 \pm 0.1 \times 10^{-6}$ & $683 \pm 3$ & $746 \pm 3$ & & & [21] \\
\hline \multirow[t]{6}{*}{9} & $\mathrm{BaO}-\mathrm{CaO}-\mathrm{Al}_{2} \mathrm{O}_{3}-\mathrm{B}_{2} \mathrm{O}_{3}-$ & 26.87 & 9.73 & & & & & $\mathrm{H}_{3} \mathrm{BO}_{3} .23 .78, \mathrm{BaCO}_{3}$ & $11.1 \times 10-6$ to & & & & & {$[22]$} \\
\hline & $\mathrm{SiO}_{2}(\mathrm{BCABS})$ & & & & & & & $\begin{array}{l}26.82, \mathrm{CaCO} 311.76, \\
\mathrm{Na}_{2} \mathrm{CO}_{3} 1.04\end{array}$ & $9.8 \times 10-6$ & & & & & \\
\hline & BCABS -10 (heat treated) & & & & & & & & & 922 & & 1040 & & {$[22]$} \\
\hline & BCABS -15 (heat treated) & & & & & & & & & 930 & & 1053 & & [22] \\
\hline & BCABS -25 (heat treated) & & & & & & & & & 936 & & 1064 & & {$[22]$} \\
\hline & BCABS -35(heat treated) & & & & & & & & & 944 & & 1075 & & {$[22]$} \\
\hline \multirow[t]{5}{*}{10} & $\begin{array}{l}\mathrm{BaCO}_{3}, \mathrm{SiO}_{2}, \mathrm{MgO}, \mathrm{CaO} \\
\text { and } \mathrm{B}_{2} \mathrm{O}_{3}\end{array}$ & 30.7 & 2.6 & 10.3 & 36 & 10.3 & 10.3 & & & & & & & \\
\hline & $\mathrm{SG} 1-1300^{\circ} \mathrm{C}-3 \mathrm{~h}$ & & & & & & & & & 596 & & 793 & 706 & [27] \\
\hline & $\mathrm{SG} 2-1300^{\circ} \mathrm{C}-3 \mathrm{~h}$ & & & & & & & & & 582 & & 751 & 697 & [27] \\
\hline & SG3-1100 ${ }^{\circ} \mathrm{C}-1 \mathrm{~h}$ & & & & & & & & & 577 & & 752 & 719 & [27] \\
\hline & SS1 & & & & & & & & & 600 & & 763 & 716 & {$[27]$} \\
\hline
\end{tabular}


In the $\mathrm{SiO}_{2}-\mathrm{B}_{2} \mathrm{O}_{3}-\mathrm{BaO}-\mathrm{MgO}$ system [16], the variation in the composition of $\mathrm{MgO}$ utilization and thermal properties has not been further observed. Certain compositions of BAS material consisting of $\mathrm{BaO}-\mathrm{Al}_{2} \mathrm{O}_{3}-\mathrm{SiO}_{2}$ [35] with one composition formulation to obtain a $\mathrm{CTE}$ value of $6.15 \times 10^{-6} \mathrm{C}^{1}$. The $\mathrm{BaO}-\mathrm{CaO}-\mathrm{SiO}_{2}$ [BCS] [36] system combines a fixed material without a certain size, using many other reinforcing components such as $\mathrm{Al}_{2} \mathrm{O}_{3}, \mathrm{~B}_{2} \mathrm{O}_{3}, \mathrm{~V}_{2} \mathrm{O}_{5}, \mathrm{ZnO}$ to observe variations in melting temperature [Tc] in the sample. Combination of $\mathrm{O}-\mathrm{Al}_{2} \mathrm{O}_{3}-\mathrm{SiO}_{2}$ [BAS] [36] material composition with $\mathrm{B}_{2} \mathrm{O}_{3}$ use control to obtain the coefficient of thermal expansion (CTE), Glass Transition ( $\mathrm{Tg}$ ) and Deformation Temperature (Td). In the $\mathrm{CaO}-\mathrm{MgO}-\mathrm{Al}_{2} \mathrm{O}_{3}-\mathrm{SiO}_{2}$ system [19], the addition of $\mathrm{Na}_{2} \mathrm{O}, \mathrm{ZrO}_{2}$, and $\mathrm{B}_{2} \mathrm{O}_{3}$ is applied to obtain the values of thermal expansion coefficient (CTE), Crystallization Temperature (Tx) and Melting Temperature (Tc). $\mathrm{CaO}-\mathrm{SiO}_{2}-\mathrm{Al}_{2} \mathrm{O}_{3}-\mathrm{MgO}$ system [37] is applied with the composition of the material in the sample but the thermal properties have not been explored.

In the $\mathrm{Y}_{2} \mathrm{O}_{3}-\mathrm{Al}_{2} \mathrm{O}_{3}-\mathrm{B}_{2} \mathrm{O}_{3}-\mathrm{SiO}_{2}$ system [26], we have used a fairly well-controlled composition ratio with the focus of observation on the coefficient of thermal expansion [CTE]. In the $\mathrm{Na}_{2} \mathrm{O}-\mathrm{SiO}_{2}$ system $[38,39]$ with a single composition formulation, the sample material is differentiated by a variety of treatments to obtain the value of the coefficient of thermal expansion (CTE), Glass Transition (Tg) and Deformation Temperature (Td). The material formulation on $\mathrm{BaO}-\mathrm{CaO}-\mathrm{Al}_{2} \mathrm{O}_{3}-\mathrm{B}_{2} \mathrm{O}_{3}-\mathrm{SiO}_{2}(\mathrm{BCABS})$ with additional material $\mathrm{H}_{3} \mathrm{BO} 3 ., \mathrm{BaCO}_{3}, \mathrm{CaCO}_{3}, \mathrm{Na}_{2} \mathrm{CO}_{3}$ [40] get the value of the coefficient of thermal expansion (CTE), Transition Glass (Tg) and Melting Temperature (Tc). The composition of $\mathrm{BaCO}_{3}, \mathrm{SiO}_{2}, \mathrm{MgO}, \mathrm{CaO}, \mathrm{B}_{2} \mathrm{O}_{3}$ materials using one formula with a variety of treatments in the sample obtained values of Glass Transition Temperature (Tg), Crystallization Temperature (Tx) and Melting Temperature (Tc) [41].

\section{Conclusions}

The development of ceramic materials for SOFC sealants has been so advanced and it is characterized by the spectrum of use of oxides as character reinforcement which is increasingly varied in variety and composition.

The wide variety of material preparation techniques, the route chosen and the various analyzes used are all aimed at obtaining the attributes of ceramics that can increasingly be met for the needs of SOFC Sealants. Not every route taken provides complete data primarily on thermal properties, so this provides ample opportunity to complement what already exists. The development of the $\mathrm{SiO} 2$ Silicate Seal is the perspective chosen as the basis for the next exciting material development, which offers ample room for in-depth review.

\section{Acknowledgement}

This research was funded by a grant from Ministry of Education and Culture of Indonesia (PTUPT-No. 257-129/UN7.6.1/PP/2020).

\section{References}

[1] Frank, Matthias, Robert Deja, Roland Peters, Ludger Blum, and Detlef Stolten. "Bypassing renewable variability with a reversible solid oxide cell plant." Applied energy 217 (2018): $101-112$. https://doi.org/10.1016/i.apenergy.2018.02.115

[2] Wincewicz, Keegan C., and Joyce S. Cooper. "Taxonomies of SOFC material and manufacturing alternatives." Journal of power sources 140, no. 2 (2005): 280-296. https://doi.org/10.1016/i.jpowsour.2004.08.032

[3] Luo, Linghong, Youchen Lin, ZuZhi Huang, Yefan Wu, Liangliang Sun, Liang Cheng, and Jijun Shi. "Application of BaOCaO-AI2O3-B2O3-SiO2 glass-ceramic seals in large size planar IT-SOFC." Ceramics International 41, no. 8 (2015): 9239-9243. https://doi.org/10.1016/i.ceramint.2015.01.091

[4] Wang, Sea-Fue, Yung-Fu Hsu, and Yueh-Chi Hsieh. "Effects of La2O3, Nd2O3, NiO and CoO additions on the characteristics of $\mathrm{SiO} 2-\mathrm{Al} 2 \mathrm{O} 3-\mathrm{Y} 2 \mathrm{O} 3-\mathrm{ZnO}$ glass seals for intermediate temperature solid oxide fuel 
cells." International Journal of Hydrogen Energy 40, no. $8 \quad$ (2015): 3338-3347. https://doi.org/10.1016/i.ijhydene.2015.01.045

[5] Partyka, Janusz, and Magdalena Leśniak. "Preparation of glass-ceramic glazes in the SiO2-Al2O3-CaO-MgO-K2ONa2O-ZnO system by variable content of ZnO." Ceramics International 42, no. 7 (2016): 8513-8524. https://doi.org/10.1016/j.ceramint.2016.02.077

[6] $\mathrm{Li}, \mathrm{Bo}$, Wei $\mathrm{Li}$, and Jingguo Zheng. "Effect of SiO2 content on the sintering kinetics, microstructures and properties of BaO-Al2O3-B2O3-SiO2 glass-ceramics for LTCC application." Journal of Alloys and Compounds 725 (2017): 10911097. https://doi.org/10.1016/i.jallcom.2017.07.251

[7] Da Silva, M. J., W. M. Pontuschka, J. F. Bartolomé, P. Jasinski, Jakub Karczewski, and S. T. Reis. "Ionic conductivity behavior by activated hopping conductivity $(\mathrm{AHC})$ of barium aluminoborosilicate glass-ceramic system designed for SOFC sealing." Journal of the European Ceramic Society 39, no. 10 (2019): 3103-3111. https://doi.org/10.1016/i.jeurceramsoc.2019.03.027

[8] Chou, Yeong-Shyung, and Jeffry W. Stevenson. "Novel infiltrated Phlogopite mica compressive seals for solid oxide fuel cells." Journal of Power Sources 135, no. 1-2 (2004): 72-78. https://doi.org/10.1016/i.jpowsour.2004.02.037

[9] Kalib, Noor Shieela, Andanastuti Muchtar, Mahendra Rao Somalu, Ahmad Kamal Ariffin Mohd Ihsan, Nurul Ashikin Mohd Nazrul Aman, and Joelle Chia Wen Mah. "Influence of heat transfer on thermal stress development in solid oxide fuel cells: A review." Journal of Advanced Research in Fluid Mechanics and Thermal Sciences 54, no. 2 (2019): 175-184.

[10] Mahato, Neelima, Amitava Banerjee, Alka Gupta, Shobit Omar, and Kantesh Balani. "Progress in material selection for solid oxide fuel cell technology: A review." Progress in Materials Science 72 (2015): $141-337$. https://doi.org/10.1016/i.pmatsci.2015.01.001

[11] Holand, Wolfram, and George H. Beall. Glass-ceramic technology. John Wiley \& Sons, 2019. https://doi.org/10.1002/9781119423737

[12] Wang, Sea-Fue, His-Chuan Lu, Yi-Xin Liu, Yung-Fu Hsu, and Zu-You Liu. "Characteristics of glass sealants for intermediate-temperature solid oxide fuel cell applications." Ceramics International 43 (2017): S613-S620. https://doi.org/10.1016/i.ceramint.2017.05.211

[13] Wang, Xiaochun, Ruizhu Li, Jiajun Yang, Dawei Gu, Dong Yan, Jian Pu, Bo Chi, and Jian Li. "Effect of YSZ Addition on the Performance of Glass-Ceramic Seals for Intermediate Temperature Solid Oxide Fuel Cell Application." International Journal of Hydrogen Energy 43, no. $16 \quad$ (2018): 8040-47. https://doi.org/10.1016/i.ijhydene.2018.03.023

[14] Chou, Yeong-Shyung, and Jeffry W. Stevenson. "Compressive mica seals for solid oxide fuel cells." Journal of materials engineering and performance 15, no. 4 (2006): 414-421. https://doi.org/10.1361/105994906X117215

[15] Liu, Liangguang, Linghong Luo, Leying Wang, Liang Cheng, Xu Xu, Yongzhi Yu, Ying Qin, and Yefan Wu. "Study on non-isothermal crystallization kinetics of the BaO-CaO-Al2O3-B2O3-SiO2 glass for IT-SOFCs sealing." Ceramics International 44, no. 17 (2018): 21277-21283. https://doi.org/10.1016/i.ceramint.2018.08.176

[16] Rodríguez-López, S., V. A. C. Haanappel, A. Durán, F. Muñoz, G. C. Mather, M. J. Pascual, and S. M. Gross-Barsnick. "Glass-ceramic seals in the system MgOBaOB2O3SiO2 operating under simulated SOFC conditions." International Journal of Hydrogen Energy 41, no. 34 (2016): 15335-15345. https://doi.org/10.1016/j.ijhydene.2016.07.051

[17] Cuevas, F. G., D. Andreouli, J. M. Gallardo, V. Oikonomou, J. Cintas, Y. Torres, and J. M. Montes. "Ceramic dies selection for electrical resistance sintering of metallic materials." Ceramics International 45, no. 12 (2019): 1455514561. https://doi.org/10.1016/j.ceramint.2019.04.172

[18] Brow, Richard K., and David R. Tallant. "Structural design of sealing glasses." Journal of Non-Crystalline Solids 222 (1997): 396-406. https://doi.org/10.1016/S0022-3093(97)90142-3

[19] Elsayed, Hamada, Hassan Javed, Antonio G. Sabato, Federico Smeacetto, and Enrico Bernardo. "Novel glass-ceramic SOFC sealants from glass powders and a reactive silicone binder." Journal of the European Ceramic Society 38 , no. 12 (2018): 4245-4251. https://doi.org/10.1016/i.jeurceramsoc.2018.05.024

[20] Batfalsky, P., V. A. C. Haanappel, J. Malzbender, N. H. Menzler, V. Shemet, I. C. Vinke, and R. W. Steinbrech. "Chemical interaction between glass-ceramic sealants and interconnect steels in SOFC stacks." Journal of Power Sources 155, no. 2 (2006): 128-137. https://doi.org/10.1016/i.jpowsour.2005.05.046

[21] Goel, Ashutosh, Dilshat U. Tulyaganov, Vladislav V. Kharton, Aleksey A. Yaremchenko, and José MF Ferreira. "Electrical behavior of aluminosilicate glass-ceramic sealants and their interaction with metallic solid oxide fuel cell interconnects." Journal of Power Sources 195, $\quad$ no. 2 (2010): 522-526. https://doi.org/10.1016/i.jpowsour.2009.08.007

[22] Cheng, Zhe, Shaowu Zha, Luis Aguilar, Dean Wang, Jack Winnick, and Meilin Liu. "A solid oxide fuel cell running on H2S/ CH4 fuel mixtures." Electrochemical and Solid State Letters 9, no. 1 (2005): A31. https://doi.org/10.1149/1.2137467

[23] Sohn, Sung-Bum, Se-Young Choi, Gyeung-Ho Kim, Hue-Sup Song, and Goo-Dae Kim. "Suitable glass-ceramic sealant 
for planar solid-oxide fuel cells." Journal of the American Ceramic Society 87, no. 2 (2004): $254-260$. https://doi.org/10.1111/i.1551-2916.2004.00254.x

[24] Lahl, N., K. Singh, L. Singheiser, K. Hilpert, and D. Bahadur. "Crystallisation kinetics in AO-Al2O3-SiO2-B2O3 glasses $(\mathrm{A}=\mathrm{Ba}, \mathrm{Ca}, \mathrm{Mg}) . "$ Journal of materials science 35, no. $12 \quad$ (2000): 3089-3096. https://doi.org/10.1023/A:1004851418274

[25] Zheng, R., S. R. Wang, H. W. Nie, and T-L. Wen. "SiO2-CaO-B2O3-Al2O3 ceramic glaze as sealant for planar ITSOFC." Journal of Power Sources 128, no. 2 (2004): 165-172. https://doi.org/10.1016/i.jpowsour.2003.10.005

[26] Kaur, Navdeep, Gurbinder Kaur, Devender Kumar, and K. Singh. "Mechanical and thermal properties of SrO/BaO modified Y2O3-Al2O3-B2O3-SiO2 glasses and their compatibility with solid oxide fuel cell components." Journal of Physics and Chemistry of Solids 118 (2018): 248-254. https://doi.org/10.1016/i.jpcs.2018.03.021

[27] Sánchez-Vázquez, A. I., J. J. Ruiz-Valdés, E. Ramírez-Blanco, A. Álvarez-Méndez, and S. M. De la Parra Arciniega. "Synthesis, characterisation and kinetic study of a glassy material in the BaO-TiO2-Ta2O5-B2O3-Al2O3 system obtained by a traditional glass fusion-casting method." Journal of non-crystalline solids 380 (2013): 65-70. https://doi.org/10.1016/i.jnoncrysol.2013.09.005

[28] Yang, Zhenguo, Jeff W. Stevenson, and Kerry D. Meinhardt. "Chemical interactions of barium-calciumaluminosilicate-based sealing glasses with oxidation resistant alloys." Solid State Ionics 160, no. 3-4 (2003): 213225. https://doi.org/10.1016/S0167-2738(03)00160-7

[29] Menzler, Norbert H., Doris Sebold, Mohsine Zahid, Sonja M. Gross, and Thomas Koppitz. "Interaction of metallic SOFC interconnect materials with glass-ceramic sealant in various atmospheres." Journal of power sources 152 (2005): 156-167. https://doi.org/10.1016/j.jpowsour.2005.02.072

[30] Singh, Raj N. "High-temperature seals for solid oxide fuel cells (SOFC)." Journal of Materials Engineering and Performance 15, no. 4 (2006): 422-426. https://doi.org/10.1361/105994906X117224

[31] Sohn, Sung-Bum, Se-Young Choi, Gyeung-Ho Kim, Hue-Sup Song, and Goo-Dae Kim. "Stable sealing glass for planar solid oxide fuel cell." Journal of non-crystalline solids 297, no. 2-3 (2002): 103-112. https://doi.org/10.1016/S00223093(01)01042-0

[32] Lara, C., M. Jesús Pascual, M. O. Prado, and Alicia Durán. "Sintering of glasses in the system RO-Al2O3-BaO-SiO2 $(\mathrm{R}=\mathrm{Ca}, \mathrm{Mg}, \mathrm{Zn})$ studied by hot-stage microscopy." Solid State lonics 170, no. 3-4 (2004): $201-208$. https://doi.org/10.1016/i.ssi.2004.03.009

[33] Borhan, A. I., M. Gromada, G. G. Nedelcu, and L. Leontie. "Influence of (CoO, CaO, B2O3) additives on thermal and dielectric properties of $\mathrm{BaO}-\mathrm{Al} 2 \mathrm{O} 3-\mathrm{SiO} 2$ glass-ceramic sealant for OTM applications." Ceramics International 42, no. 8 (2016): 10459-10468. https://doi.org/10.1016/j.ceramint.2016.03.199

[34] Puig, Jean, Andreas Prange, Baptiste Arati, Charles Laime, Pascal Lenormand, and Florence Ansart. "Optimization of the synthesis route of a barium boron aluminosilicate sealing glass for SOFC applications." Ceramics International 43, no. 13 (2017): 9753-9758. https://doi.org/10.1016/i.ceramint.2017.04.151

[35] Smeacetto, Federico, Milena Salvo, Monica Ferraris, J. Cho, and A. R. Boccaccini. "Glass-ceramic seal to join Crofer 22 APU alloy to YSZ ceramic in planar SOFCs." Journal of the European Ceramic Society 28, no. 1 (2008): 61-68. https://doi.org/10.1016/i.jeurceramsoc.2007.05.006

[36] Brendt, Jeerawan, Sonja-M. Gross-Barsnick, Carole Babelot, and Ghaleb Natour. "The influence of ZnO and V2O5 on the crystallization behavior of $\mathrm{BaO}-\mathrm{CaO}-\mathrm{SiO} 2$ glass-ceramic sealants." Journal of Non-Crystalline Solids 501 (2018): 78-84. https://doi.org/10.1016/i.jnoncrysol.2018.01.032

[37] Esfahani, Shaghayegh, and Mansoor Barati. "Effect of slag composition on the crystallization of synthetic CaOSiO2-Al2O3-MgO slags: Part I-Crystallization behavior." Journal of Non-Crystalline Solids 436 (2016): 35-43. https://doi.org/10.1016/i.jnoncrysol.2015.12.011

[38] Da Silva, Maviael J., Jose F. Bartolome, H. Antonio, and Sonia Mello-Castanho. "Glass ceramic sealants belonging to BAS (BaO-AI2O3-SiO2) ternary system modified with $\mathrm{B} 2 \mathrm{O} 3$ addition: A different approach to access the SOFC seal issue." Journal of the European Ceramic Society 36, no. 3 (2016): 631-644. https://doi.org/10.1016/i.jeurceramsoc.2015.10.005

[39] Lin, Dewei, Shengwei Tan, Fen Lin, Zhengwei Dong, Jiajia Yan, Dian Tang, Hsiwen Yang, Kongfa Chen, and Teng Zhang. "Improving the sealing performance of glass-ceramics for SOFCs applications by a unique 'composite'approach: a study on Na2O-SiO2 glass-ceramic system." Journal of the European Ceramic Society 38, no. 13 (2018): 4488-4494. https://doi.org/10.1016/j.jeurceramsoc.2018.06.005

[40] Liu, Wenning, Xin Sun, and Mohammad A. Khaleel. "Predicting Young's modulus of glass/ceramic sealant for solid oxide fuel cell considering the combined effects of aging, micro-voids and self-healing." Journal of Power Sources 185, no. 2 (2008): 1193-1200. https://doi.org/10.1016/j.jpowsour.2008.07.017

[41] Nielsen, K. A., M. Solvang, S. B. L. Nielsen, A. R. Dinesen, D. Beeaff, and P. H. Larsen. "Glass composite seals for SOFC application." Journal of the European Ceramic Society 27, no. 2-3 (2007): 1817-1822. https://doi.org/10.1016/i.jeurceramsoc.2006.05.046 